\title{
Benefits and Challenges of Online Food Ordering and Delivery Service - with Special Reference to Working Women in Chennai
}

\author{
K. Shyamala, R. Subhasri
}

\begin{abstract}
Online food delivery services like Zomato, Swiggy, Uber eats etc., is very common in Chennai, serving food to the customers at their doorstep in round the clock. This study was basically conducted to analyse the benefits and challenges of online food delivery services and its relationship with the socioeconomic aspects of the working women in Chennai. This study was aimed to explore the benefits and challenges of online food deliver and to find the relationship between demographic profile of the working women and factors of online food delivery. : The study mainly depends on the Primary data collected through a well-structured Questionnaire distributed to in Chennai alone. The result shows that there is Perfect association between age and educational qualification of the working women and cluster groups.
\end{abstract}

Keywords: Online food delivery, Benefits, Services and satisfaction.

\section{INTRODUCTION}

Technology and Internet have paved the progression in various sectors like Research, Communication, Banking, Textile, and Medicine including Food industry also. Like online purchase of goods, phone-based to online ordering of food is also familiar through a web page or app. Online food delivery services like Zomato, Swiggy, Uber eats etc., is very common in Chennai, serving food to the customers at their doorstep in round the clock. This study was basically conducted to analyse the benefits and challenges of online food delivery services and its relationship with the socioeconomic aspects of the working women in Chennai.

\section{REVIEW OF LITERATURE}

Sethu H S \& Bhavya Saini (2016), investigated the student's perception, behaviour and satisfaction of online food ordering and delivery services and the study reveals that online food purchasing services help the students in managing their time better. It is also found that ease of availability of their desired food at any time and at the same time easy access of internet are the prime reasons for using the online food services.

Revised Manuscript Received on December 05, 2019.

* Correspondence Author

Dr. Mrs. K. Shyamala, Assistant Professor, Department of BCOM-Corporate Secretaryship S. D. N. B. Vaishnav College for Women,

Dr. Mrs. R. Subhasri, Assistant Professor, Department of BCOM S.D.N.B.Vaishnav College for Women, Chennai, India. Chennai, India.

Neha Parashar Ms Sakina Ghadiyali (2017), aims to find the most popular food app in food delivery industry. 129 respondents were taken for the study to analyse the customers' usage of food delivery apps and their socio economic characteristics. Structured questionnaire was tested through Cronbach alpha. Statistical tools like chi-square, weighted average and descriptive analysis were used. The study reveals that, consumers selecting food delivery app on the basis of facilities offered for the purchase and cash on delivery is the preferred mode for the payment.

Jyotishman Das (2018) analyzed the consumers' perception towards online food ordering and delivery services in Pune City. By using Non probability sampling method, data was collected from 153 online food app users. It is identified that, consumers prefer Zomato and Swiggy online food service providers because of good rewards and cashbacks offers provided by them.

Karishm Sharma, Karee Abdul Waheed (2018) tried to identify how the consumers use online food ordering app. Standard survey collection method has been adopted to collect the questionnaires from the Expatriate college students in Dubai. The sample size taken was 45 students and tools applied were percentage analysis. The results reveals that zomato is a most favourable online food ordering app and spent between 51-100 AED at a reasonable amount to order the food.

Suryadev Singh Rathore and Mahik Chaudhary (2018) analysed the consumers' preference and the factors which influence the consumers to order the food in online. By using structured questionnaire, data was collected from 120 respondents of Indore City. The study reveals that youngsters are attached to Ubereats and Zomato online ordering services. Discounted prices and offers, convenience and on- time delivery are mainly influencing the consumers to order in online app.

\section{OBJECTIVES OF THE STUDY}

- To study the socio- economic aspects of the working women in Chennai.

- To know the working women's perception towards online food service in Chennai

- To analysis the benefits and challenges of online food delivery.

Published By:

Blue Eyes Intelligence Engineering 
Benefits and Challenges of Online Food Ordering and Delivery Service - with Special Reference to Working Women in Chennai

- $\quad$ To find the relationship between demographic profile of the working women and factors of online food delivery.

\section{Hypotheses}

There is no association between the cluster groups of working women and its demographic profile.

\section{METHODOLOGY}

Area of the Study: The study is confined to Chennai City only.

Sample Size: Since the population for the survey are very large, and due to time limitation a sample size of 100 is taken for the survey.

\section{Sources of Data}

- Primary Data: Survey method is employed to collect the data from the respondents and the data are collected.

- Secondary Data: The secondary data was collected from various journals, magazines, books, articles, research papers and websites.

Research Tools: Percentage analysis, t-test, cluster analysis and chi-square analysis have been applied

Sampling Method: The study mainly depends on the Primary data collected through a well-structured Questionnaire distributed to in Chennai alone. The Secondary data was collected from journals, magazines, books, articles, research papers and websites.

Data Instrument: Well-structured Questionnaire

\section{LIMITATIONS}

- The Research Area was confined to Chennai Only.

- Sample size was only 100

- Respondent's opinion differs from time to time

\section{RESULTS AND DISCUSSION}

Table - 1: Socio- Economic Aspects of the Respondents

\begin{tabular}{|l|l|l|}
\hline Age (In Years) & Frequency & Percentage \\
\hline $20-30$ & & \\
\hline $30-40$ & 37 & 37 \\
\hline $40-50$ & 41 & 41 \\
\hline Above 50 & 15 & 15 \\
\hline Academic Qualification & 7 & 7 \\
\hline School Level & 10 & 10 \\
\hline Diploma & 19 & 19 \\
\hline Graduate & 49 & 49 \\
\hline Post Graduate & 22 & 22 \\
\hline Occupation & & \\
\hline Professional & 24 & 24 \\
\hline Government Employee & 27 & 27 \\
\hline Business & 21 & 21 \\
\hline MNC \& Other Private Sector & 28 & 28 \\
\hline
\end{tabular}

The above table reveals that, the maximum of, $41 \%$ of the respondents falls under the age group of 30-40 years, $49 \%$ of the working women are graduates; $28 \%$ of the women working in MNC and other private sectors, $53 \%$ of the respondents are married and $46 \%$ of the women earning the monthly income of Rs 60,000 and above.

Table - 2: Online Food Service Aspects

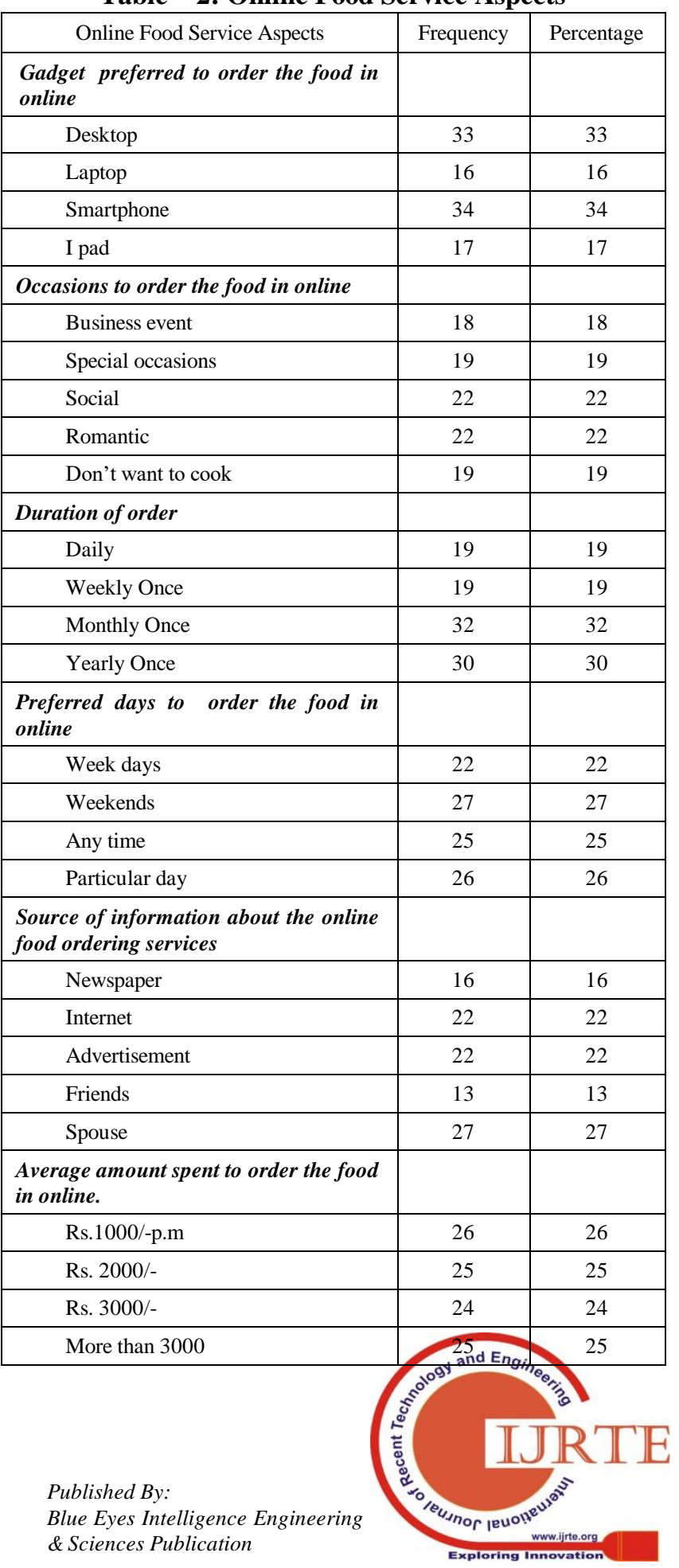




\begin{tabular}{|c|c|c|}
\hline Preferred mode for payment & & \\
\hline Internet transaction & 28 & 28 \\
\hline Cash on delivery & 42 & 42 \\
\hline Credit Card & 30 & 30 \\
\hline $\begin{array}{l}\text { Online food services has affected the } \\
\text { traditional way of dining together }\end{array}$ & & \\
\hline Yes & 20 & 20 \\
\hline No & 31 & 31 \\
\hline May be & 26 & 26 \\
\hline Neutral & 23 & 23 \\
\hline
\end{tabular}

The above table show that, maximum of, $34 \%$ of the respondents, preferred smart phone gadget to order the food in online, $22 \%$ of the women order their food in romantic and social events and occasions. $32 \%$ of the respondents ordering their food monthly once, $27 \%$ of the survey unit preferred only weekends to order the food in online, $27 \%$ of the users came to know about this service through their spouse.

It also found that, majority of, $26 \%$ of the working women spent, Rs.1000/- per month for ordering the food in online. $42 \%$ of the respondents preferred, cash on delivery to pay the value for food purchased in online and $31 \%$ of the users agree that buying food in online do not affect the traditional way of dinning.

Table - 3: Ranking of Mean and One-Sample Statistics for online food ordering and delivery services

\begin{tabular}{|l|c|c|c|c|c|}
\hline $\begin{array}{l}\text { Name of the } \\
\text { food service }\end{array}$ & t-value & Mean (SD) & $\begin{array}{c}\text { Std. } \\
\text { Error } \\
\text { Mean }\end{array}$ & Sig & Rank \\
\hline Food Panda & 17.878 & $4.47(2.50)$ & .250 & $\begin{array}{c}.00 \\
0\end{array}$ & 3 \\
\hline Uber eats & 20.567 & $4.70(2.28)$ & .228 & $\begin{array}{c}.00 \\
0\end{array}$ & 1 \\
\hline Daily cary & 18.225 & $4.18(2.29)$ & .229 & $\begin{array}{c}.00 \\
0\end{array}$ & 8 \\
\hline Zomato & 20.544 & $4.59(2.23)$ & .223 & $\begin{array}{c}.00 \\
0\end{array}$ & 2 \\
\hline $\begin{array}{l}\text { Pizza Hut } \\
\text { Delivery }\end{array}$ & 19.439 & $4.27(2.20)$ & .219 & $\begin{array}{c}.00 \\
0\end{array}$ & 6 \\
\hline Dominos & 20.751 & $4.36(2.10)$ & .210 & $\begin{array}{c}.00 \\
0\end{array}$ & 5 \\
\hline Runnr & 19.070 & $4.25(2.167)$ & .2167 & $\begin{array}{c}.00 \\
0\end{array}$ & 7 \\
\hline Swiggy & 19.615 & $4.44(2.328)$ & .233 & $\begin{array}{c}.00 \\
0\end{array}$ & 4 \\
\hline
\end{tabular}

From the above table it is clear that, Uber eats Online food delivery services(4.7000) ranked first, Second and third preference goes to Zomato(4.5900) and food panda (4.4700)respectively and next places occupied by Swiggy (4.4400), Dominos (4.3600), Pizza Hut delivery (4.2700), Runnr (4.2500) and Daily cary (4.1800) respectively.

The one sample t-values $(17.878,20.567,18.225,20.544$, $19.439,20.751,19.070,19.615)$ are statistically significant at $5 \%$ level. This shows that working women are strongly agreed to order the food in online delivery services.

Table - 4: One-Sample Statistics and Ranking Analysis on Benefits of using an Online food delivery service

\begin{tabular}{|l|c|c|c|c|c|}
\hline $\begin{array}{l}\text { Benefits } \\
\text { Factor }\end{array}$ & t-Value & $\begin{array}{c}\text { Mean } \\
\text { (SD) }\end{array}$ & $\begin{array}{c}\text { Std. } \\
\text { Error }\end{array}$ & Sig & Rank \\
\hline
\end{tabular}

\begin{tabular}{|c|c|c|c|c|c|}
\hline & & & Mean & & \\
\hline Convenience & 22.197 & $\begin{array}{c}3.28 \\
(1.48)\end{array}$ & .148 & .000 & 1 \\
\hline $\begin{array}{c}\text { Quick } \\
\text { Delivery. }\end{array}$ & 20.014 & $\begin{array}{c}2.85 \\
(1.42)\end{array}$ & .142 & .000 & 7 \\
\hline Time Saving & 20.252 & $\begin{array}{c}2.97 \\
(1.47)\end{array}$ & .147 & .000 & 3 \\
\hline $\begin{array}{c}\text { Availability of } \\
\text { options }\end{array}$ & 18.476 & $\begin{array}{c}2.88 \\
(1.56)\end{array}$ & .156 & .000 & 6 \\
\hline $\begin{array}{c}\text { Ease of menu } \\
\text { selection }\end{array}$ & 21.131 & $\begin{array}{c}2.94 \\
(1.39)\end{array}$ & .139 & .000 & 5 \\
\hline $\begin{array}{c}\text { Ease of } \\
\text { payment }\end{array}$ & 21.732 & $\begin{array}{c}2.97 \\
(1.37)\end{array}$ & .137 & .000 & 3 \\
\hline $\begin{array}{c}\text { Better deals } \\
\text { and discounts } \\
\text { and attractive } \\
\text { offers }\end{array}$ & 23.054 & $\begin{array}{c}3.10 \\
(1.34)\end{array}$ & .134 & .000 & 2 \\
\hline $\begin{array}{c}24 \times 7 \\
\text { Availability }\end{array}$ & 19.800 & $\begin{array}{c}2.81 \\
(1.42)\end{array}$ & .142 & .000 & 8 \\
\hline $\begin{array}{c}\text { Door step } \\
\text { Delivery }\end{array}$ & 19.738 & $\begin{array}{c}2.94 \\
(1.49)\end{array}$ & .149 & .000 & 5 \\
\hline
\end{tabular}

It is evident from the above table that, Factor "Convenience"- is ranked first and agreed by the respondents with the mean value of 3.2800 ,"Better deals and discounts and attractive offers"- is ranked second and agreed with the mean value of 3.1000, "Ease of payment"- is ranked third and also agreed by the consumers with the mean value of 2.9700 and next places occupied by Ease of menu selection(2.9400),Door step Delivery (2.9400), Availability of options (2.8800), Quick Delivery(2.8500) and24 x 7 Availability (2.8100) respectively..

The t-values of above Factors $(22.197,23.054,21.732$, $21.131,19.738,18.476,20.014,19.800)$ are statistically significant at $5 \%$ level. This shows that all the benefits are influencing the working women to order and get the food in online food delivery services.

Table - 5: One-Sample Statistics and Ranking Analysis on Challenges of using an Online food delivery service

\begin{tabular}{|c|c|c|c|c|c|}
\hline $\begin{array}{c}\text { Challenging } \\
\text { Factors }\end{array}$ & t-value & $\begin{array}{c}\text { Mean } \\
\text { (SD) }\end{array}$ & $\begin{array}{c}\text { Std. } \\
\text { Error } \\
\text { Mean }\end{array}$ & Sig & Rank \\
\hline $\begin{array}{c}\text { Reduced freshness } \\
\text { of food }\end{array}$ & 20.045 & $\begin{array}{c}2.89 \\
(1.44)\end{array}$ & .144 & .000 & 6 \\
\hline $\begin{array}{c}\text { Product below } \\
\text { expectations }\end{array}$ & 21.250 & $\begin{array}{c}3.02 \\
(1.42)\end{array}$ & .142 & .000 & 4 \\
\hline Waiting time & 20.628 & $\begin{array}{c}2.96 \\
(1.43)\end{array}$ & .143 & .000 & 5 \\
\hline $\begin{array}{c}\text { Technically } \\
\text { difficult to use }\end{array}$ & 21.548 & $\begin{array}{c}3.06 \\
(1.42)\end{array}$ & .142 & .000 & 3 \\
\hline $\begin{array}{c}\text { Inability to return } \\
\text { the dish if not } \\
\text { appetizing/spoilt }\end{array}$ & 23.373 & $\begin{array}{c}3.24 \\
(1.39)\end{array}$ & .139 & .000 & 1 \\
\hline $\begin{array}{c}\text { Inability to revise } \\
\text { the order once } \\
\text { placed. }\end{array}$ & 21.079 & $\begin{array}{c}3.08 \\
(1.46)\end{array}$ & .146 & .000 & 2 \\
\hline
\end{tabular}

From the above table, it is clear that the mean values range 3.2400 to 2.8900 with respective standard Deviation. The ranking analysis is applied on these mean values and identified that, "Inability to return the dish if not appetizing /spoilt" ranks first, 
Benefits and Challenges of Online Food Ordering and Delivery Service - with Special Reference to Working Women in Chennai

"Inability to revise the order once placed" ranks second and "Technically difficult to use "ranks third.

The t-values of above Factors $(23.373,21.079,21.548$, $21.250,20.628,20.045)$ are statistically significant at $5 \%$ level. This shows that all the challenges in online food ordering and delivery services are influencing the working women. So this inconvenience can be considered by the online food ordering services to achieve their target easily.

\section{A. Cluster Analysis}

Cluster analysis implies that three major classifications, identification of three groups of working women is used in K-Mean Cluster Analysis to obtain the results shown in the table

Table - 6: Frequency Loading of Clusters of Chennai working women

\begin{tabular}{|c|c|c|}
\hline \multirow{3}{*}{ Cluster } & Traditional women & 27.000 \\
\cline { 2 - 3 } & Trendy women & 40.000 \\
\cline { 2 - 3 } & Modern women & 33.000 \\
\hline \multicolumn{2}{|c|}{ Valid } & 100.000 \\
\hline
\end{tabular}

B. Association between Cluster Group And Demographic Variable Of The Working Women

Table - 7: Cross tabulation cluster and age

\begin{tabular}{|c|c|c|c|c|c|}
\hline \multirow{2}{*}{$\begin{array}{l}\text { Cluster } \\
\text { Group }\end{array}$} & \multicolumn{4}{|c|}{ Age (In Years) } & \multirow{2}{*}{ Total } \\
\hline & Below 20 & 20 - 30 & $30-40$ & $\begin{array}{c}\text { Above } \\
50\end{array}$ & \\
\hline $\begin{array}{c}\text { Traditional } \\
\text { women }\end{array}$ & 11 & 14 & 1 & 1 & 27 \\
\hline $\begin{array}{l}\text { Trendy } \\
\text { women }\end{array}$ & 16 & 17 & 7 & 0 & 40 \\
\hline $\begin{array}{l}\text { Modern } \\
\text { women }\end{array}$ & 10 & 10 & 7 & 6 & 33 \\
\hline Total & 37 & 41 & 15 & 7 & 100 \\
\hline & $\begin{array}{r}\text { Pear } \\
\text { As } \\
1\end{array}$ & $\begin{array}{l}\text { n chi Squ } \\
\text { np. Sig. (2 } \\
\text { pothesis }\end{array}$ & $\begin{array}{l}\text { e } 14.744 \\
\text { ided) } .02 \\
\text { Rejected }\end{array}$ & & \\
\hline
\end{tabular}

Table - 8: Cross tabulation Custer and Marital status

\begin{tabular}{|c|c|c|c|}
\hline \multirow{2}{*}{ Cluster Group } & \multicolumn{2}{|c|}{ Marital Status } & \multirow{2}{*}{ Total } \\
\hline & Married & Un Married & \\
\hline Traditional women & 14 & 13 & 27 \\
\hline Trendy women & 22 & 18 & 40 \\
\hline Modern women & 17 & 16 & 33 \\
\hline Total & 53 & 47 & 100 \\
\hline & $\begin{array}{l}\text { Chi-Squa } \\
\text { Sig. (2-si } \\
\text { thesis - Ac }\end{array}$ & & \\
\hline
\end{tabular}

Table - 9: Cross tabulation Cluster and Occupation

\begin{tabular}{|c|c|c|c|c|c|}
\hline \multirow{2}{*}{$\begin{array}{c}\text { CLUSTE } \\
\text { R } \\
\text { GROUP }\end{array}$} & Professional & $\begin{array}{c}\text { Govt. } \\
\text { Employee }\end{array}$ & $\begin{array}{c}\text { Busine } \\
\text { ss }\end{array}$ & $\begin{array}{c}\text { MNC } \\
\mathbf{8} \\
\text { other } \\
\text { Private } \\
\text { Sector }\end{array}$ & Total \\
\hline Traditional & 5 & 13 & 6 & 3 & 27 \\
\hline
\end{tabular}

Table - 10: Cross tabulation Cluster and Income

\begin{tabular}{|c|c|c|c|c|c|}
\hline \multirow{2}{*}{ CLUSTER GROUP } & \multicolumn{4}{|c|}{ INCOME (In Rs.) } & \multirow{2}{*}{ Total } \\
\hline & $\begin{array}{l}\text { Below } \\
20,000\end{array}$ & $\begin{array}{c}20,000 \\
-40,000\end{array}$ & $\begin{array}{c}40,000 \\
-60,000\end{array}$ & $\begin{array}{l}\text { Above } \\
60,000\end{array}$ & \\
\hline Traditional women & 5 & 3 & 6 & 13 & 27 \\
\hline Trendy women & 9 & 7 & 2 & 22 & 40 \\
\hline Modern women & 7 & 6 & 9 & 11 & 33 \\
\hline Total & 21 & 16 & 17 & 46 & 100 \\
\hline \multicolumn{5}{|c|}{ Hypothesis - Accepted } & \\
\hline
\end{tabular}

Table - 11: Cross tabulation Cluster and educational Qualification

\begin{tabular}{|c|c|c|c|c|c|}
\hline \multirow{2}{*}{$\begin{array}{c}\text { CLUSTER } \\
\text { GROUP }\end{array}$} & \multicolumn{4}{|c|}{ EDUCATIONAL QUALIFICATION } & \multirow{2}{*}{ Total } \\
\cline { 2 - 5 } level & diploma & graduation & Post-graduation & \\
\hline $\begin{array}{c}\text { Traditional } \\
\text { women }\end{array}$ & 5 & 3 & 6 & 13 & 27 \\
\hline $\begin{array}{c}\text { Trendy } \\
\text { women }\end{array}$ & 9 & 7 & 2 & 22 & 40 \\
\hline $\begin{array}{c}\text { Modern } \\
\text { women }\end{array}$ & 7 & 6 & 9 & 11 & 33 \\
\hline Total & 21 & 16 & 17 & 46 & 100 \\
\hline \multicolumn{7}{|c|}{ Pearsonchi-Square309.929(a) and Asymp. Sig. (2-sided).000 } \\
\hline
\end{tabular}

\section{Hypotheses Testing}

As the p-value is less than .05 , it is statisticallysignificant at $5 \%$ level. Thus, null hypothesis is rejected. This shows that there is Perfect association between age and educational qualification of the working women and cluster groups.

\section{CONCLUSION}

In recent days, middle class people are confused and surprised because of inflated bill in the restaurant (GST). In the restaurant, huge tax margin is levying for the comfortable dining and waiter to serve it at a table. Online food delivery services come as a rescue, to get their food in their place itself at special offers and discounts. Specifically, Convenience makes the working women to use this technology and to get the cooked food at their doorstep that too at reasonable price. Old method of traditional dining is also possible through online food delivery services. 


\section{REFERENCES}

1. Jyotishman das (2018), "Consumers perception towards online food ordering and delivery services - An empirical study", Journal of Management, Volume 5, Issue 5, Sep - oct, pp155-163.

2. KarishmSharma, karee Abdul Waheed (2018),"consumption of online food app service : An exploratory study among college students in Dubai”, Middle East Journal Of Business 13(4):411,

3. Kline, R.B (2011) principles and practice of structural equation modeling (3rded.). New York NY: Guilford press.

4. NehaParasharMs.SakinaGhadiyali( 2017) “ A study on customer's attitude and perception towards digital food app services", Amity journal of Management.(2017)

5. Sethu H S and BhavyaSaini (2016), "Consumer perception and Satisfaction on Ordering Food via Internet, a case of Foodzoned.com, in Manipal", proceeding of the seventh Asia- pacific Conference on Gobal Business, Economics , Finance and Social Sciences, Kuala Lumpur, Malasia, pp 15-17.

6. Suryadev Singh Rathore and MahikChaudhary (2018), "Consumers perception on online food ordering IJMBS, Volume 8, October to December, pp 12- 17

7. West S.G, Finch J.F and Curran P.J (1995). Structural equation models with nonnormal variables: Problems and remedies in R. H. Hoyle (ed), structural equation modeling: concepts, and applications (pp 56-75) Thousand Oaks, CA, US: Sage Publications, inc.

\section{AUTHORS PROFILE}

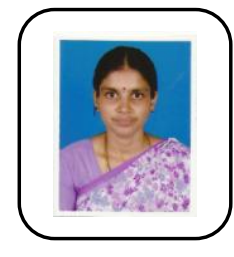

Dr. K. Shyamala, is currently Assistant Professor, Department of Department of Corporate Secretaryship, Shrimati Devkunvar Nanalal Bhatt Vaishnav College for Women, Chromepet, Chennai - 600 044. She holds a doctoral degree with specialization in marketing, Her subject interests range from social marketing, consumer behaviour, attitude, digital marketing, online shopping and brand management.

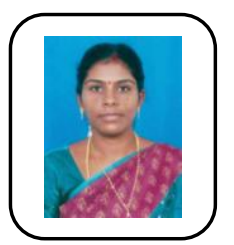

Dr. R. Subhasri, After completing M.Phil., I started my career as Assistant Professor in the esteemed college S.D.N.B.Vaishnav college for women, B.Com (Cs) Department in the year 2006. Sharing my knowledge and taking Accounts classes is my passion. In 2010, my career transferred to B.Com (Gen) Department and I got the opportunity to serve as Assistant professor in PG department of Commerce and now I am the Head In-charge for B.Com (Professional Accounting) Department. Various portfolio during my career - Autonomous valuation camp officer, EDP Co-ordinator, Smriti convenor, Admission co-ordinator and placement co- ordinator. 